\title{
The Impact of Localized Organization Factors Which Contribute To Improve in Reducing Project Delay of Property Development Company in Selangor, Malaysia
}

\section{Tan Tien Shen, Dania Sammani}

To Link this Article: http://dx.doi.org/10.6007/IJARBSS/v12-i1/12358

DOI:10.6007/IJARBSS/v12-i1/12358

Received: 24 November 2021, Revised: 27 December 2021, Accepted: 15 January 2022

Published Online: 30 January 2022

In-Text Citation: (Shen \& Sammani, 2022)

To Cite this Article: Shen, T. T., \& Sammani, D. (2022). The Impact of Localized Organization Factors Which Contribute To Improve in Reducing Project Delay of Property Development Company in Selangor, Malaysia. International Journal of Academic Research in Business and Social Sciences, 12(1), 2791-2800.

Copyright: (c) 2022 The Author(s)

Published by Human Resource Management Academic Research Society (www.hrmars.com)

This article is published under the Creative Commons Attribution (CC BY 4.0) license. Anyone may reproduce, distribute, translate and create derivative works of this article (for both commercial and non0-commercial purposes), subject to full attribution to the original publication and authors. The full terms of this license may be seen at: http://creativecommons.org/licences/by/4.0/legalcode

Vol. 12, No. 1, 2022, Pg. $2791-2800$

Full Terms \& Conditions of access and use can be found at http://hrmars.com/index.php/pages/detail/publication-ethics 


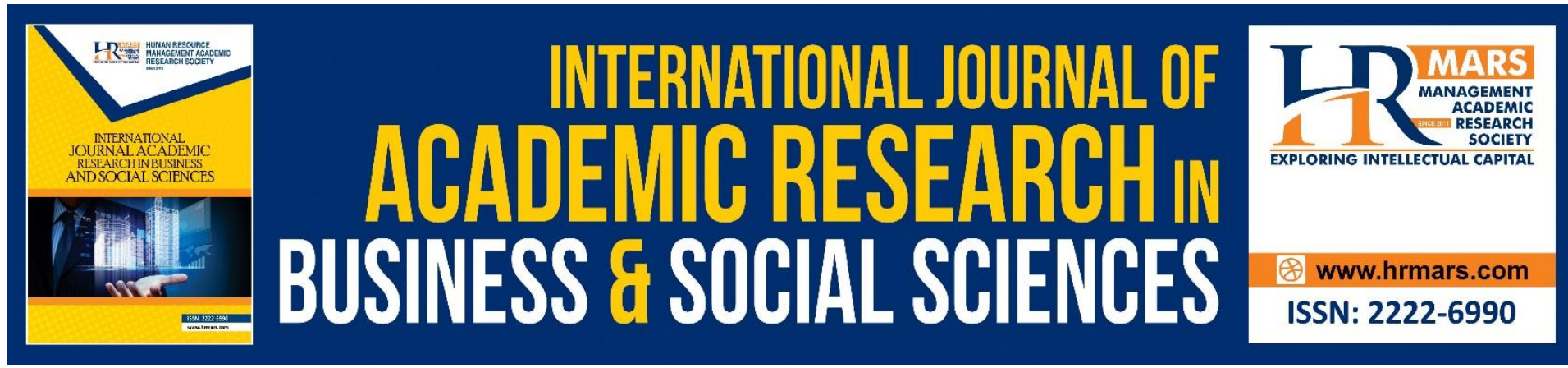

\title{
The Impact of Localized Organization Factors Which Contribute To Improve in Reducing Project Delay of Property Development Company in Selangor, Malaysia
}

\author{
Tan Tien Shen, Dania Sammani \\ Tunku Abdul Rahman University College, Malaysia
}

\begin{abstract}
Despite the evolution and availability of various project management approaches in the literature, housing project delays are still occurring in Malaysia, according to statistics from the Ministry of Housing and Local Government Malaysia. As a result, a different research approach is needed in project management to address this issue (AISehaimi, Koskela, \& Tzortzopoulos, 2013). The aim is to use a localised alternative research methodology to examine the factors that contribute to the reduction of project delays by focusing on a few key factors, such as organization factors in property developers in Selangor, Malaysia. The study also looked at whether the demographic profiles of the respondents had anything to do with the differences in the project's success factors. The study's target audience was project managers working for a property developer in Selangor, Malaysia. A total of 50 respondents were selected to take part in the survey. As a result of researching localised organization causes of delays at a property development company in Selangor, Malaysia. It is possible to create a conceptual model that will aid in the reduction of project delays. Rather than a universal conceptual model.
\end{abstract}

Keywords: Project, Delays, Organization Factors, Property Developer, Selangor, Malaysia, Project Management.

\section{Introduction}

Malaysia is a fast-growing Asian nation whose economy has traditionally depended heavily on agriculture, forest ranger services, oil, and other industries. This vision has been influenced by company contribution that is contingent on the substantial and efficient execution of project management operations. In this situation, project management implementation in Malaysia is rapidly evolving.

Almost every project now uses it, including government, construction, telecommunications, information technology, education, and banking. Awareness and productive project management is crucial to an organization's success in rising productivity success. For security, success, and capacity, many Malaysian organisations depend on project managers' skills and responsibilities to implement for project success. 
Government's economic development initiatives need to analyse successful project management processes in order to bring the country's economic growth to a serious level. In achieving effective project management in operations.

Despite advances in construction project management techniques, delay is undeniably a critical factor that can be used as a critical factor in project performance as researchers provide clues about project progress. A number of factors have contributed to the delay in projects, especially housing.

Delays can be caused by a variety of factors, such as "Delay in material transportation which happened in the Philippines' on "Air Terminal Construction Adventure," or machine or transmission failure in the "Xieng Khouang Road Development." It all depends on whether or not a building project achieves its targets while remaining on budget.

Cost invasion is a major issue that is almost always connected to building projects. This is becoming more pronounced in non-industrialized countries, where these results often exceed some of the typical project costs.

Despite the fact that project management strategies are widely used in the construction industry today, previous research has revealed a poor track record in managing project projects to resolve issues, especially those involving costs and delays. Several projects in the group that establishes cost and time constraints have failed.

The key issue is that the project is running behind schedule and will be completed late. Similarly, considering the evolution and availability of numerous project management approaches in the literature, the problem is not fully solved (AlSehaimi et al., 2013).

According to (Portal Rasmi Jabatan Perumahan Negara, 2021), the housing delay in Selangor is the largest, with 10,951 units of housing affected as of October 2021. A total of 8,008 property buyers in the Malaysian state of Selangor have been impacted by the housing development delays.

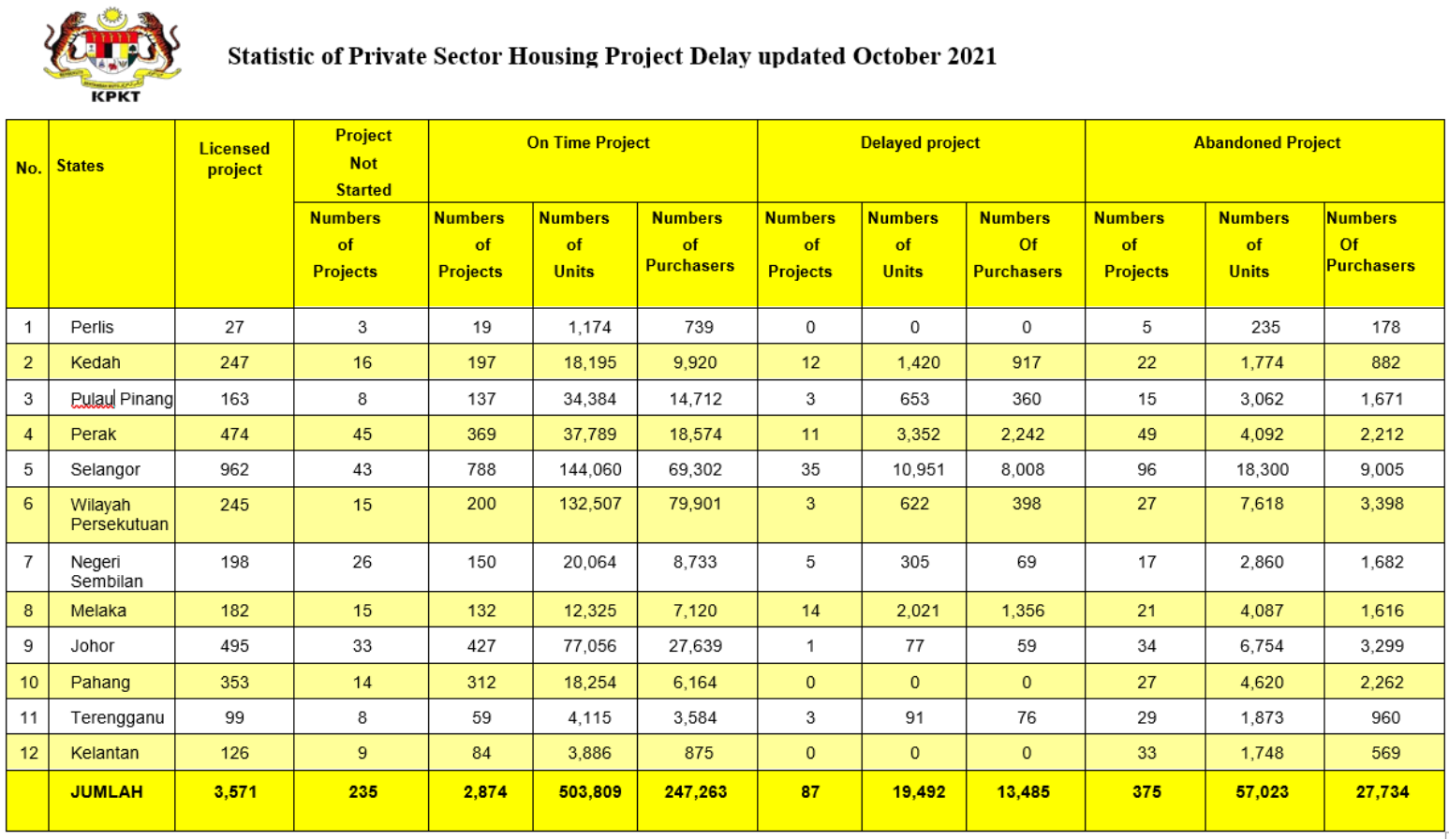

Table 1. Statistic of Private Sector Housing Project Delay (Portal Rasmi Jabatan Perumahan Negara, 2021) 


\section{Literature Review}

Property developers in Malaysia play two major roles: land acquisition and the launch of development activities. Some developers hire a construction management company, while others hire contractors through a competitive bidding process. 2008 (Anikeeff \& Sriram) Property development operation are choosing to lease even their company's buildings in order to expand capacity and lower borrowing costs, so property developers manage a significant portion of this private sector job. The property developer is the most reluctant member of an innovative product's supply chain because of the perceived risks of acceptance.

(McCoy et al., 2009) The property developer has a tremendous responsibility to ensure that his or her project is done correctly, but this is not always the case. In-house design and planning, project financing, project execution/management, project definition/formulation, legal agreements, schedule urgency and length, social elements, and more are all responsibilities of the developer.

According to (Ezebilo, 2020), property developers could play a significant role in the development of cityscapes and the assessment of environmental consequences. Developers seek regulatory certainty and organisational flexibility, while governments seek assurance that developers can meet environmental, social, and infrastructure development goals (Taylor et al., 2012).Throughout the year, numerous causes of project delays in housing projects have been reported. Organization factors, Financial factors, and Project Manager Factors are among the most significant.

For financial factors, since project funding is a major problem for the construction industry, it is the most significant factor that causes delays and cost overruns (Frimpong et al., 2003). Unresolved project funding would have a negative impact on client company and project manager management (Muya et al., 2013), client payment withholding (Booyens et al., 2015), and contractor's unfounded argument (Booyens et al., 2015). (El-Kholy \& Akal, 2019). As a consequence of all of these factors, the project will be substantially delayed.

For project manager factors, (Alvarenga et al., 2019) stated that a project manager is in charge of ensuring that a project is effective in terms of cost and technical efficiency. He is a project manager who uses his expertise, talents, and experiences to ensure that the project is finished on schedule and on budget (Sumner et al., 1999). Job assignments can overlap during construction due to a lack of proper planning and control (Arachchige, 2014). Human resource induction and preparation would have a direct negative impact on job effectiveness (Memon et al., 2014). Failure in making decision and correct action efficiently may result the need for change order due to cost increment and the construction will being delayed. (2019, Gonfa) Bad project management would have a direct effect on the subordinates' lives, causing them to lack direction and purpose. As a consequence of all of these factors, the project will be substantially delayed. However, the aim of this study is to find a localised alternative.

For organization factors, (Dissanayake, 2006) stated organizational is a process of collective consciousness development that occurs when actors collaborate to achieve mutually agreed goals. The interaction of participants, mutual sense-making, and the formation of meaning in the organizational context are defined as the key mechanisms of organizational construction in this sense. More specifically, it supports the notion that 
organizational rationality, efficacy, and performance, as well as the organizational environment, are all time- and context-bound constructs. As a consequence of all of these factors, the project will be substantially delayed. Therefore we would breakdown the subfactors for project manager that causes the project delay as follows (Table 2 ) :

\begin{tabular}{|c|c|c|c|}
\hline No & Organization Sub-factors & Description & Reference \\
\hline 1 & $\begin{array}{l}\text { Poor organization of } \\
\text { consultant and contractor }\end{array}$ & $\begin{array}{l}\text { Poor organization of consultant and contractor problem is not only hurt } \\
\text { your ability to maximize opportunities, but it can also create problems } \\
\text { that can lead to serious financial consequences and project delays. }\end{array}$ & (Milano, 2019) \\
\hline 2 & Organizational leadership & $\begin{array}{l}\text { Organizational leadership involves processes and proximal outcomes } \\
\text { such as worker commitment that contribute to the development and } \\
\text { achievement of organizational goals. }\end{array}$ & $\begin{array}{c}\text { (Zaccaro and } \\
\text { Klimoski, 2002), }\end{array}$ \\
\hline 3 & Suspension of work & $\begin{array}{l}\text { Suspension of work during construction generally means that } \\
\text { construction is stopped until all contract activities under the contract } \\
\text { are completed. }\end{array}$ & (Lee, 2018) \\
\hline 4 & $\begin{array}{l}\text { Overall organizational } \\
\text { culture profile }\end{array}$ & $\begin{array}{l}\text { Organizational culture is a reflection of the basic hypothesis shared by } \\
\text { the members of a group, which defines how the group views itself and } \\
\text { its environment and the way it conducts its daily activities. }\end{array}$ & $\begin{array}{l}\text { (Picchio et al., } \\
\text { 2020) }\end{array}$ \\
\hline 5 & $\begin{array}{l}\text { Change of the partner in } \\
\text { the project organizational }\end{array}$ & $\begin{array}{l}\text { Partnershipsometimes referred to as alliance, for example in the rail } \\
\text { sector) is a broad term used to describe a collaborative management } \\
\text { approach that encourages openness and trust between contracting } \\
\text { parties. }\end{array}$ & $\begin{array}{l}\text { (Partnering in } \\
\text { construction, } \\
\text { 2020) }\end{array}$ \\
\hline 6 & $\begin{array}{l}\text { Inappropriate overall } \\
\text { organization structure } \\
\text { linked to the project }\end{array}$ & $\begin{array}{l}\text { Inappropriate overall organization structure linked to the project means } \\
\text { that decisions are made and executed in an organization with an } \\
\text { inappropriate structure. }\end{array}$ & (Kenton, 2020) \\
\hline 7 & Deficiencies in organization & $\begin{array}{l}\text { Organization deficiencies include deficiencies in your buildings, plants, } \\
\text { employees, systems and operations. To identify organization } \\
\text { weaknesses, review documents to see if you are meeting your goals. }\end{array}$ & $\begin{array}{c}\text { (Toor and } \\
\text { Ogunlana, 2008) }\end{array}$ \\
\hline 8 & $\begin{array}{l}\text { Shortage of technical } \\
\text { professionals in the } \\
\text { contractor's organization }\end{array}$ & $\begin{array}{l}\text { Shortage of technical professionals in the contractor's organization is } \\
\text { also one of the reason that cause project delay.Skills shortages in the } \\
\text { construction industry have been a concern in the infrastructure sector } \\
\text { for years. }\end{array}$ & (Thomson, 2015) \\
\hline 9 & $\begin{array}{l}\text { Safety rules and regulations } \\
\text { are not followed within the } \\
\text { contractor's organization }\end{array}$ & $\begin{array}{l}\text { Site safety is a sensitive issue with extensive regulations and } \\
\text { specialized departments to deal with it. The large number of reported } \\
\text { deaths and injuries caused by work-related injuries raised the need for } \\
\text { regulation. }\end{array}$ & (Wilson, 2012) \\
\hline 10 & $\begin{array}{l}\text { Worker-management } \\
\text { relationship }\end{array}$ & $\begin{array}{l}\text { Employee relationship management is the process that management } \\
\text { uses to effectively manage all interactions with employees and } \\
\text { ultimately achieve organizational goals. }\end{array}$ & $\begin{array}{c}\text { (Zhang et al., } \\
\text { 2019) }\end{array}$ \\
\hline 11 & $\begin{array}{l}\text { Weak consultant } \\
\text { organization and } \\
\text { experience }\end{array}$ & $\begin{array}{l}\text { Consultants are expected to provide specific services to their clients } \\
\text { based on their expertise. In terms of content, Consultants need to } \\
\text { facilitate and help clients understand their own organizations and their } \\
\text { processes. }\end{array}$ & $\begin{array}{l}\text { (Williams and } \\
\text { Mason, 2014) }\end{array}$ \\
\hline 12 & $\begin{array}{l}\text { Slow decision making and } \\
\text { bureaucracy in Client } \\
\text { Organization }\end{array}$ & $\begin{array}{l}\text { Bureaucratic organizations are formal and highly organized, with } \\
\text { organizational charts for each department. This is because rules and } \\
\text { regulations in bureaucracies are often rigid and inflexible which causes } \\
\text { slow decision thinking. }\end{array}$ & (Kukreja, 2018) \\
\hline
\end{tabular}

Table 2 : 12 sub-factors of project manager causes of project delay. 
The critical factors, which include project manager factors, financial factors, and organization factors, will be considered independent variable in this analysis, while project success in reducing delays is dependent variable. This is because project success in reducing delays is dependent on the Critical factors.

It shows a direct cause and effect relationship between independent and dependent variable of the study.

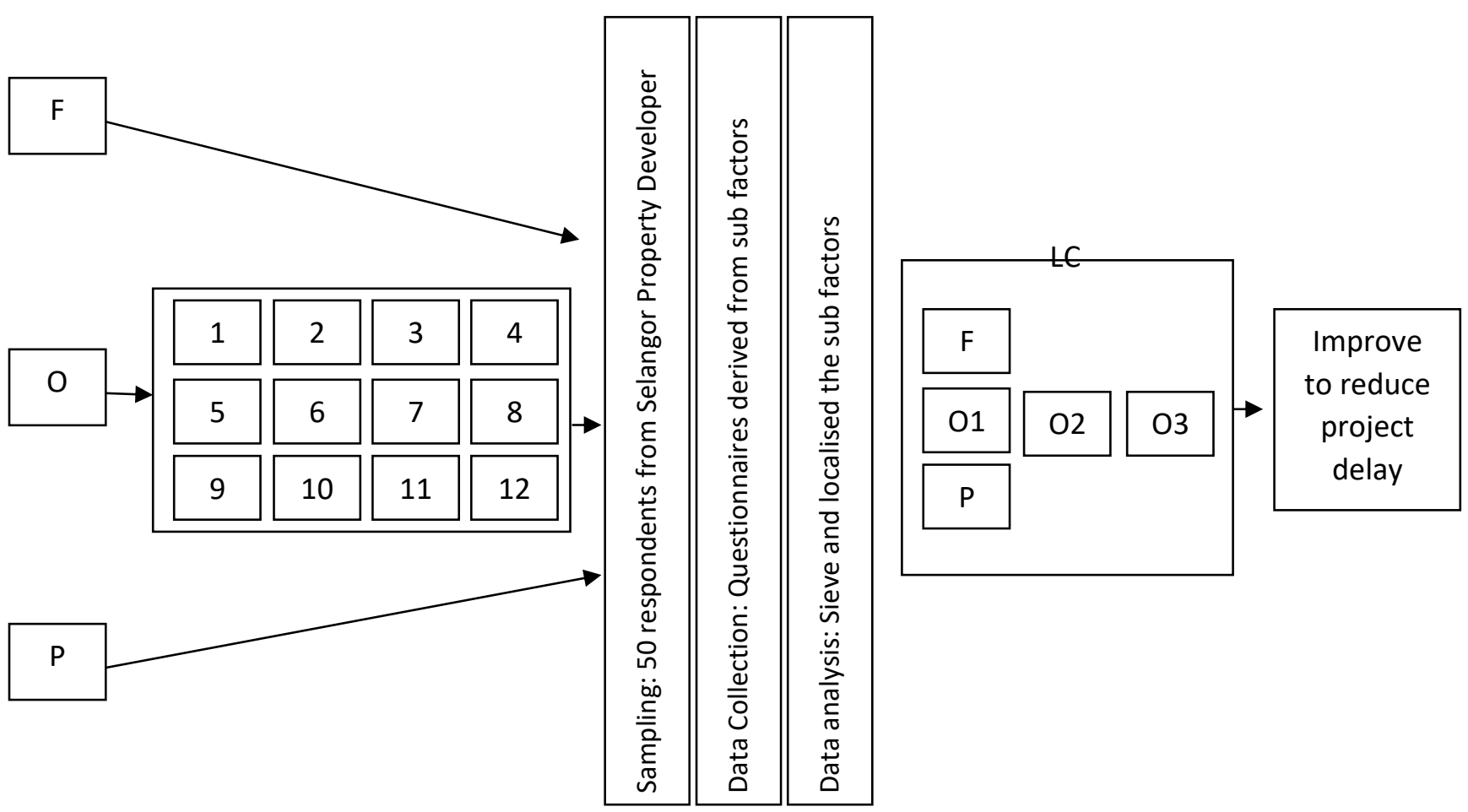

Figure 1. Conceptual Model of study between O(Organization factor ), P( Project Manager factor ),F (Financial factors),1,2,3,4,5,6,7,8,9,10,11,12(Organization subfactor in table 2) and LC( Localized Caused for Project Delay)

\section{Source : Self proposed}

This study uses a survey tool to collect data on the topic of critical factors to minimise project delay in Selangor, Malaysia. The three factors analysed are (a) organisational factors, (b) financial factors, and (c) project manager factors.

Project managers from organisations in Selangor, Malaysia, make up the target population. The tool's questions are designed to address all of the variables analysed. In the analysis, there are three factors and twelve subfactors that are investigated in the three factors of organisation, financial, and project manager.

The tool used for this survey is a group of questionnaires that use different scales, including the Likert scale.

The Likert scale asks respondents to respond to a series of proclamations by showing whether they strongly disagree, disagree, neutral, agree, or strongly agree with each statement. Each response is related to a score, and a person's score is determined by adding scores in each link. 
The questionnaire is divided into two areas as follows: Part 1: consists of 50 questions identified with the 12 sub-factors in table 3. Area 2: contains questions identified by the respondent's demographics, e.g. B. Gender, ability, long participation times.

A research based on table 2 will be used to collect data on the investigated variables. It will be adapted to the region around Selangor, Malaysia, and will cover additional aspects that relate to the presented questionnaire.

Survey data can be collected manually or sent via email. Then all corresponding answers are collected in a dataset in Microsoft Excel, which can be used in the statistical software package. Statistical Package Social Sciences (SPSS) for Measurable Research. The investigation is performed using descriptive investigation, reliability test and sample t-test. The descriptive research consisted of examining the profiles of the respondents. For example, the survey will determine the gender level of the respondents, the time or knowledge of people in project management, the type of industry.

The 50 respondents were randomly selected from a number of organizations affiliated with project management exercises in property developer in Selangor, Malaysia using the following questionnaire Table 3 which derived from Table 2. 
INTERNATIONAL JOURNAL OF ACADEMIC RESEARCH IN BUSINESS AND SOCIAL SCIENCES Vol. 12, No. 1, 2022, E-ISSN: 2222-6990 @ 2022 HRMARS

\begin{tabular}{|c|c|c|c|c|c|c|}
\hline No & $\begin{array}{l}\text { Question of Organization Sub- } \\
\text { factors That Causes Delay }\end{array}$ & $\begin{array}{l}\text { Strongly } \\
\text { disagree }\end{array}$ & Disagree & Neutral & Agree & $\begin{array}{l}\text { Strongly } \\
\text { agree }\end{array}$ \\
\hline 1 & $\begin{array}{l}\text { Poor organization of } \\
\text { consultant and contractor }\end{array}$ & & & & & \\
\hline 2 & Organizational leadership & & & & & \\
\hline 3 & Suspension of work & & & & & \\
\hline 4 & $\begin{array}{l}\text { Overall organizational culture } \\
\text { profile }\end{array}$ & & & & & \\
\hline 5 & $\begin{array}{l}\text { Change of the partner in the } \\
\text { project organizational }\end{array}$ & & & & & \\
\hline 6 & $\begin{array}{l}\text { Inappropriate overall } \\
\text { organization structure linked } \\
\text { to the project }\end{array}$ & & & & & \\
\hline 7 & Deficiencies in organization & & & & & \\
\hline 8 & $\begin{array}{l}\text { Shortage of technical } \\
\text { professionals in the } \\
\text { contractor's organization }\end{array}$ & & & & & \\
\hline 9 & $\begin{array}{l}\text { Safety rules and regulations } \\
\text { are not followed within the } \\
\text { contractor's organization }\end{array}$ & & & & & \\
\hline 10 & $\begin{array}{l}\text { Worker-management } \\
\text { relationship }\end{array}$ & & & & & \\
\hline 11 & $\begin{array}{l}\text { Weak consultant organization } \\
\text { and experience }\end{array}$ & & & & & \\
\hline 12 & $\begin{array}{l}\text { Slow decision making and } \\
\text { bureaucracy in Client } \\
\text { Organization }\end{array}$ & & & & & \\
\hline
\end{tabular}

Table 3 : Questionnaires derived from Table 2.

\section{Conclusion}

The study to be conducted in Selangor is to identify the crucial organizational sub-factors for effectively reduce project delays. The role of organisational, financial, and project 
manager factors in minimising project delays has been also widely documented in the literature.

Using data from 50 respondents in a Property Developer based in Selangor, Malaysia, several new findings will also highlight the value of some important organization subfactors that need to be addressed to reduce delay.

From this study, property developer company will be able to localise and effectively address the crucial sub-factor to minimise project delay for potential housing projects in Selangor by using the conceptual model in Figure 1.

\section{Acknowledgement}

We would like to thank the people involved in making this article published. Not forgeting the faculty and university to trust us. Finally, thanks to our family and friends who have supported us all this time.

\section{Corresponding Author}

Ts. Tan Tien Shen

Department of Quantity Surveying, Faculty of Built Environment, Tunku Abdul Rahman University College

Email: Jtienshen77@gmail.com

\section{References}

\section{Journal Article}

AlSehaimi, A., Koskela, L., \& Tzortzopoulos, P. (2013). Need for Alternative Research Approaches in Construction Management: Case of Delay Studies. Journal of Management in Engineering, 29(4), 407-413. https://doi.org/10.1061/(asce)me.19435479.0000148

Alvarenga, J. C., Branco, R. R., Guedes, A. L. A., Soares, C. A. P., \& Silva, W. da S. (2019). The project manager core competencies to project success. International Journal of Managing Projects in Business, 13(2), 277-292. https://doi.org/10.1108/IJMPB-12-20180274

Anikeeff, M. A., \& Sriram, V. (2008). Construction management strategy and developer performance. Engineering, Construction and Architectural Management, 15(6), 504513. https://doi.org/10.1108/09699980810916951

Arachchige, B. (2014). Absence of Induction and its Impact on the Organization. The IUP Journal of Management Research, (2), 7-16.

Booyens, D., Farrell, S., Garnett, D., \& Perreira, R. (2015). The effect of client interference on construction projects in South Africa. Proceedings of The 3rd Virtual Multidisciplinary Conference, 3(December), 271-278. https://doi.org/10.18638/quaesti.2015.3.1.222

El-Kholy, A. M., \& Akal, A. Y. (2019). Determining the stationary financial cause of contracting firms failure. International Journal of Construction Management, 0(0), 1-16. https://doi.org/10.1080/15623599.2019.1584836

Ezebilo, E. E. (2020). Evaluation of construction, marketing and management in housing delivery by a private developer: evidence from Papua New Guinea. Journal of Housing and the Built Environment, (0123456789). https://doi.org/10.1007/s10901-020-09730-y

Frimpong, Y., Oluwoye, J., \& Crawford, L. (2003). Causes of delay and cost overruns in construction of groundwater projects in a developing countries; Ghana as a case study. International Journal of Project Management, 21(5), 321-326. 
https://doi.org/10.1016/S0263-7863(02)00055-8

Gonfa, B. D. (2019). Effects of Poor Leadership Skill in Organization : Evidences. Arabian Journal of Business and Review, 9(2), 1-5.

McCoy, A. P., Thabet, W., \& Badinelli, R. (2009). Understanding the role of developer/builders in the concurrent commercialization of product innovation. European Journal of Innovation Management, 12(1), 102-128.

https://doi.org/10.1108/14601060910928193

Memon, A. H., Rahman, I. A., \& Hasan, M. F. A. (2014). Significant causes and effects of variation orders in construction projects. Research Journal of Applied Sciences, Engineering and Technology, 7(21), 4494-4502. https://doi.org/10.19026/rjaset.7.826

Muya, M., Kaliba, C., Sichombo, B., \& Shakantu, W. (2013). Cost escalation, schedule overruns and quality shortfalls on construction projects: The case of Zambia. International Journal of Construction Management, 13(1), 53-68.

https://doi.org/10.1080/15623599.2013.10773205

Sumner, M. (1999). Critical success factors in enterprise wide information management systems projects. Proceedings of the ACM SIGCPR Conference, 297-303. https://doi.org/10.1145/299513.299722

Taylor, B. M., Harman, B. P., Heyenga, S., \& McAllister, R. R. J. (2012). Property Developers and Urban Adaptation: Conceptual and Empirical Perspectives on Governance. Urban Policy and Research, 30(1), 5-24. https://doi.org/10.1080/08111146.2011.639178

\section{Online Articles}

Portal Rasmi Jabatan Perumahan Negara. Ehome.kpkt.gov.my. (2021). Retrieved 14 March 2021, from https://ehome.kpkt.gov.my/index.php/pages/view/79. 